\title{
Effect of Various Pretreatment Methods on Bioethanol Production from Cotton Stalks
}

\author{
Konstantinos Dimos ${ }^{1,+}$, Thomas Paschos ${ }^{1,+}$, Argiro Louloudi ${ }^{2}$, Konstantinos G. Kalogiannis ${ }^{3}$, \\ Angelos A. Lappas ${ }^{3}$, Nikolaos Papayannakos ${ }^{2}$, Dimitris Kekos ${ }^{1}$ and Diomi Mamma ${ }^{1, * \mathbb{C}}$ \\ 1 Biotechnology Laboratory, School of Chemical Engineering, National Technical University of Athens, \\ Zografou Campus, 15780 Athens, Greece; konstantinosdimos@windowslive.com (K.D.); \\ thom.paschos@gmail.com (T.P.); kekos@chemeng.ntua.gr (D.K.) \\ 2 Chemical Process Engineering Laboratory, School of Chemical Engineering, National Technical University \\ of Athens, Zografou Campus, 15780 Athens, Greece; louloudi.iro@gmail.com (A.L.); \\ npap@central.ntua.gr (N.P.) \\ 3 Laboratory of Environmental Fuels and Hydrocarbons, Chemical Process and Energy Resources \\ Institute (CPERI), Centre for Research and Technology Hellas (CERTH), 6th km Harilaou-Thermi Rd, \\ 57001 Thessaloniki, Greece; kkalogia@cperi.certh.gr (K.G.K.); angel@cperi.certh.gr (A.A.L.) \\ * Correspondence: dmamma@chemeng.ntua.gr; Tel.: +30-210-7723158 \\ + These authors contributed equally to this paper.
}

Received: 3 December 2018; Accepted: 20 December 2018; Published: 1 January 2019

\begin{abstract}
Cotton stalks (CS) are considered a good candidate for fuel-ethanol production due to its abundance and high carbohydrate content, but the direct conversion without pretreatment always results in extremely low yields due to the recalcitrant nature of lignocelluloses. The present study was undertaken to investigate the effect of various chemical and physicochemical pretreatment methods, i.e., alkali, microwave-assisted acid, organosolv, hydrothermal treatment, and sequentially organosolv and hydrothermal pretreatment, on chemical composition of CS and subsequent ethanol production applying pre-hydrolysis and simultaneous saccharification and fermentation (PSSF) at high solid loading. The best results in terms of ethanol production were achieved by the sequential combination of organosolv and hydrothermal pretreatment $(32.3 \mathrm{~g} / \mathrm{L}$, using $15 \% w / v$ substrate concentration and $6 \mathrm{~h}$ pre-hydrolysis) with an improvement of $32 \%$ to $50 \%$ in ethanol production compared to the other pretreatments. Extending pre-hydrolysis time to $14 \mathrm{~h}$ and increasing substrate concentration to $20 \% w / v$, ethanol production reached $47.0 \mathrm{~g} / \mathrm{L}$ (corresponding to an ethanol yield of $52 \%$ ) after $30 \mathrm{~h}$ of fermentation.
\end{abstract}

Keywords: cotton stalks; alkali pretreatment; hydrothermal treatment; microwave-assisted acid pretreatment; organosolv; bioethanol; high solids pre-hydrolysis and simultaneous saccharification and fermentation

\section{Introduction}

The global economy can no longer depend on fossil fuels and non-renewable carbon and thus in the last two decades, global research programs on alternative energy have been directed towards discovering new and sustainable energy sources [1].

Depletion of fossil fuels, accumulation of atmospheric $\mathrm{CO}_{2}$, increasing energy demand, national energy security and rural economic development are the main reasons bringing about a transitional change from a fossil fuel based economy to a more sustainable carbon-neutral bio-economy, where agriculture not only will continue to provide food security but also biomass as a renewable raw material for industry $[1,2]$. 
Biomass, like agricultural crop residues such as wheat straw, corn stover, rice straw, and cotton stalks, forestry residues, grasses, sawdust, wood chips offers a promising source for biofuels because it is abundant, inexpensive and does not compete with food and feed applications. Ethanol derived from biomass has the potential to be renewable transportation fuel due to several advantageous properties [3].

Cotton plant is an important crop playing a key role in economic, political and social affairs of the world [4]. According to Food and Agricultural Organization of the United Nations cotton production in 2014 was approximately 26 million tones worldwide [5]. Cotton stalk (CS), a by-product of cotton production, generated in huge volumes annually, approximately 2 metric tons of dry matter/ha, is a major low-cost source of sugars that can be converted into bio-based products such as fuel ethanol [6].

The typical scheme of bioethanol production from lignocellulosic biomass involves pre-treatment, hydrolysis, fermentation, and product separation/purification [3]. The main components of lignocelllulosic biomass i.e., cellulose, hemicellulose and lignin, are strongly intermeshed and bonded through covalent or non-covalent bonds forming the lignocellulosic matrix. Therefore, the degradation of any of the above class of ingredients is subject to the constraints caused by other ingredients, resulting in relatively low digestibility of raw lignocellulosic biomass [7,8]. Pretreatment is thus, a crucial step for bioethanol production from lignocellulosic materials causing changes in microstructure, macrostructure and chemical composition of lignocellulose in order to obtain a solid phase enriched in cellulose and more susceptible to enzymatic attack [7]. To be efficient any selected pretreatment method should improve the availability of monomeric sugars, prevent their degradation, avoid inhibitor formation and be low cost [9]. Pretreatment methods can be classified as physical, chemical, physico-chemical, biological methods and their combinations $[7,8]$. Chemical and physico-chemical pretreatment technologies were extensively used for lignocellulosic biomass, although both technologies demonstrate distinct action mechanisms for cell wall destruction. For instance, the outcome of the dilute acid or hydrothermal pretreatment is the hydrolysis of hemicellulose components while alkali or organosolv pretreatment targets mainly lignin [10-13]. A single pretreatment method alone is not always effective and therefore combined pretreatment methods have been recently considered as a promising approach for higher ethanol yield [7].

The processes generally used in fermentation of lignocellulosic materials are simultaneous saccharification and fermentation (SSF) and separate hydrolysis and fermentation (SHF). The SHF process has been traditionally used except SSF is superior for ethanol production since it can get better ethanol yields by removing end product inhibition and eliminates the need for separate reactors. This process is also cost effective although difference in optimum temperature conditions of enzyme for hydrolysis and fermentation poses some restrictions [14]. Ethanol concentration in the fermentation broth superior to $4 \%(w / v)$ is considered a prerequisite to diminish the energy demand in the distillation stage [15]. In order to achieve ethanol concentration of $4 \%(w / v)$, the amount of sugars released in the hydrolysis step should be at least $80 \mathrm{~g} / \mathrm{L}$, hence high-solids loadings ( $>15 \%$ solids) are required during enzymatic hydrolysis [16]. Operating hydrolysis at high solid loading creates technical difficulties due to high initial viscosity of the material, which makes mixing difficult resulting in mass and heat transfer problems [17]. Pre-hydrolysis and the Simultaneous Saccharification and Fermentation (PSSF) process, is a variation of the SSF process, where the substrate is subjected to a pre-hydrolysis step at optimum temperature for cellulolytic enzymes $\left(50^{\circ} \mathrm{C}\right)$ followed by fermentation of the resulted slurry. By PSSF reduction of viscosity of the solid-liquid mixture can be achieved prior to the addition of the microorganism [17].

The aim of this work was to evaluate the potential of CS as a feedstock for high titer ethanol production. In this context, different chemical (alkali, organoslov), physico-chemical (hydrothermal, microwave-assisted acid pretreatment) and combined pretreatment methods (organosolv followed by hydrothermal treatment) were examined. Compositional analysis of the pretreated materials was conducted. The process configuration for ethanol production applied was PSSF at high solids loading. 
Parameters that influenced the performance of PSSF such as substrate concentration and length of pre-hydrolysis time were also examined.

\section{Materials and Methods}

\subsection{Raw Material and Reagents}

Cotton stalks (CS) were obtained from the Laboratory of Farm Mechanization, Department of Agriculture, Crop Production and Rural Environment, University of Thessaly. Prior to compositional analysis, the biomass which consisted primarily of stalks, leaves and cotton residue, was ground to a particle size of $3 \mathrm{~mm}$. Commercial cellulase Cellic ${ }^{\circledR} \mathrm{CTec} 2$ was kindly provided by Novozymes Corporation (Bagsværd, Denmark). All chemicals were analytical grade, provided by Sigma S.A. (St. Louis, MO, USA).

\subsection{Pretreatment of Cotton Stalks}

\subsubsection{Hydrothermal Treatment}

Hydrothermal treatment of biomass and organosolv treated CS was carried out in a Hastelloy C-276 Parr autoclave with a volume of $975 \mathrm{~cm}^{3}$. A total of $30 \mathrm{~g}$ of solid feedstock were fed into the reactor and $300 \mathrm{~g}$ of distilled water were then poured so as to achieve a liquid to solid ratio of 10:1 w/w. The reactor was tightly sealed and pressurized up to 12 bars with $\mathrm{N}_{2}$. Temperature was set at $175{ }^{\circ} \mathrm{C}$ and reaction time was $2 \mathrm{~h}$ in all cases. Heat up and cool down times were around $15 \mathrm{~min}$ each. The reaction mixture was filtered to separate the solid residues from the liquid phase. Distilled water was used to wash the solid residue and the washing water was mixed with the liquid sample received from the hydrolysis. The solid residue was dried overnight in an oven at a low temperature of $50{ }^{\circ} \mathrm{C}$ and mass constancy was checked the following day to ensure total removal of residual moisture. More details can be found elsewhere [18].

\subsubsection{Microwave-Assisted Acid Pretreatment}

Microwave-assisted acid pretreatment was conducted as described elsewhere [19]. Briefly, a microwave digestion equipment (speed waveTM MWS-2, Berghof Instruments GmBH, Eningen, Germany) was employed for substrate pretreatment, operating at microwave power of $700 \mathrm{~W}$. The charge of solids, measured by the liquor to solid ratio (LSR), was kept at $6.7 \mathrm{~g} \cdot \mathrm{g}^{-1}$. The experimental settings were $210{ }^{\circ} \mathrm{C}, 10 \mathrm{~min}$ in the presence of $2 \mathrm{~g}$ sulfuric acid $/ 100 \mathrm{~g}$ of dry CS. The pretreated solid was filtered, washed thoroughly with deionized water, dried in an air-circulated oven overnight at $50{ }^{\circ} \mathrm{C}$ to remove all residual moisture, and used for the subsequent fermentation experiments.

\subsubsection{Alkali Treatment}

Conditions for alkali treatment of CS were adopted from a previous study [20]. Briefly, aqueous solution of $\mathrm{NaOH}$ at concentration $1.5 \%(w / v)$ was used to pretreat CS sample at a solid loading of $15 \%(w / v)$ (corresponding to $10 \mathrm{~g} \mathrm{NaOH} / 100 \mathrm{~g}$ of CS). Treatments were performed in an autoclave at $121^{\circ} \mathrm{C}$ with $15 \mathrm{psi}(103.4 \mathrm{kPa})$ pressure for residence time of $30 \mathrm{~min}$. The pretreated solid was filtered, washed thoroughly with deionized water, dried in an air-circulated oven overnight at $50{ }^{\circ} \mathrm{C}$ to remove all residual moisture and used for the subsequent fermentation experiments.

\subsubsection{Organosolv Treatment}

Single stage Milox cooking were carried out in $500 \mathrm{~cm}^{3}$ conical flasks at atmospheric pressures. Formic acid (FA) was used at a 10:1 solvent to biomass weight ratio. Hydrogen peroxide (HP) was added at a concentrations of $2 \mathrm{wt} . \%$ on solvent, and the reaction temperature was $80^{\circ} \mathrm{C}$. Typically, $30 \mathrm{~g}$ of biomass were treated in each run for reaction time of $1 \mathrm{~h}$. The biomass was suspended in the FA and heated up to the desired temperature prior to the $\mathrm{H}_{2} \mathrm{O}_{2}$ addition. The delignified biomass samples were 
filtered and washed with six volumes of the corresponding solvent. Finally, the resulting pulp was washed with distilled water and dried in an oven overnight at $50{ }^{\circ} \mathrm{C}$ to remove all residual moisture and used for the subsequent fermentation experiments. Further details can be found elsewhere [18].

\subsection{Bioconversion of Pretreated CS to Ethanol}

Pretreated CS at concentration of $15 \%(w / v)$ was subjected to pre-hydrolysis using $80 \mathrm{FPU} / \mathrm{g}$ cellulose of Cellic ${ }^{\circledR}$ CTec2 at $50 \pm 0.5{ }^{\circ} \mathrm{C}$ and pH 5.0 in an orbital shaker (200 $\left.\pm 2 \mathrm{rpm}\right)$ for $6 \mathrm{~h}$ unless otherwise stated. Following pre-hydrolysis, compressed baker's yeast (Yiotis, Athens, Greece) corresponding to $15 \mathrm{mg}$ yeast per gram of dry pretreated CS was added in all cases, while no nutrients supplemented the fermentation broth. Fermentation was carried out in an orbital shaker at $30 \pm 0.5^{\circ} \mathrm{C}$, initial pH 5.0 and $80 \pm 2 \mathrm{rpm}$. At certain time intervals, samples were withdrawn and analyzed for ethanol. All experiments were conducted in duplicate.

\subsection{Analytical Methods}

Total cellulase activity (FPU), glucose and ethanol concentration were determined as described elsewhere [20]. Structural carbohydrate content (cellulose and hemicellulose) and lignin of native CS as well as of the pretreated CS samples was determined according to the laboratory analytical procedure (LAP) of National Renewable Energy Laboratory [21]. For each sample, the carbohydrate content analysis was carried out in triplicate.

\subsection{Calculations}

The following equations were used for the calculation of glucose potential (Equation (1)), maximum theoretical ethanol (Equation (2)), hydrolysis yield (Equation (3)) and ethanol yield (Equtaion (4)).

$$
\begin{gathered}
{\left[G_{\text {potential }}\right]=f \cdot\left[S_{0}\right] \cdot 1.111,} \\
{\left[\text { EtOH }_{\text {theoretical }}\right]=0.511 \cdot f \cdot\left[S_{0}\right] \cdot 1.111,} \\
H Y(\%)=\frac{\left[\text { Glucose }_{t}-\text { Glucose }_{0}\right]}{f \cdot\left[S_{0}\right] \cdot 1.111}, \\
\operatorname{TEY}(\%)=\frac{\left[E t O H_{t}-E_{t O H}\right]}{0.511 \cdot f \cdot\left[S_{0}\right] \cdot 1.111},
\end{gathered}
$$

where, $\left[G_{\text {potential }}\right]$ is the maximum (theoretical) amount of glucose that could be released if all cellulose in the biomass converts to glucose $(\mathrm{g} / \mathrm{L}),\left[E_{t O H} H_{\text {theoretical }}\right]$ the maximum (theoretical) ethanol that could be produced from the cellulose present in the biomass (g/L), HY hydrolysis yield (\%), TEY theoretical ethanol yield $(\%),\left[S_{0}\right]$ is the initial biomass concentration $(\mathrm{g} / \mathrm{L}),\left[\right.$ Glucose $_{t}-$ Glucose $\left._{0}\right]$ is the glucose produced during pre-hydrolysis $(\mathrm{g} / \mathrm{L}),\left[E_{t O H}-E t O H_{0}\right]$ is the ethanol produced during fermentation $(\mathrm{g} / \mathrm{L}), f$ is the cellulose fraction of the biomass, 0.511 is the conversion factor for glucose to ethanol and 1.111 is the conversion factor for cellulose to equivalent glucose.

\section{Results and Discussion}

\subsection{Composition of Native and Pretreated CS}

Native CS used in the present study, contained $37.9 \%$ (w/w dry basis) cellulose and $14.7 \%(w / w$ dry basis) hemicellulose [20]. Lignin, the major barrier in enzymatic hydrolysis of cellulose, was found to be $25.8 \%(w / w)$. In the literature, cellulose content of native CS ranged from $30 \%$ to $39.8 \%(w / w)$ while hemicellulose from $10.7 \%$ to $16.7 \%(w / w)$. The total lignin content of CS is comparable to that reported elsewhere (approximately $27 \%$ to 30\%, w/w) [4,22,23]. According to Agblevor et al. [24] composition of CS varies depending on the growing location, season, harvesting methods, as well 
as analysis procedures. The total holocellulose content (sum of cellulose and hemicellulose) of CS is $52.7 \%(w / w)$, making CS a potential feedstock for ethanol production. The total polysaccharide content of cotton stalk can be fairly compared with other extensively explored lignocellulosic materials, such as sugarcane bagasse, $67.1 \%$; corn stover, $58.3 \%$; wheat straw, $54.0 \%$; and sorghum straw, $61.0 \%$; and widely accepted switch grass, $52.9 \%$, for ethanol production [6].

In the present study, chemical and physico-chemical pretreatments were applied to CS. More specifically, CS was subjected to alkali, microwave-assisted acid, organosolv, hydrothermal treatment and combination of the organosolv and hydrothermal treatment. Compositional analysis of the solid residue after each pretreatment revealed that varying amounts of hemicellulose and lignin remained in the biomass, which might affect the fermentable sugar release (Table 1).

Hydrothermal pretreatment is an environmentally friendly pretreatment method, maintains water in the liquid state at elevated temperatures $\left(160-240{ }^{\circ} \mathrm{C}\right)$ and high pressures in order to promote disintegration and separation of the lignocellulosic matrix. During hydrothermal treatment, most of hemicellulose and part of lignin could be degraded [11]. In the present study, CS was subjected to hydrothermal pretreatment at $175^{\circ} \mathrm{C}$ for $2 \mathrm{~h}$ and led to a solid recovery of $67 \%(w / w)$ on dry basis. Cellulose content in the solid residue after pretreatment was found to be $47.3 \%(w / w)$ (corresponding to a cellulose recovery of $83.5 \%$ ), while approximately $82 \%$ of hemicellulose was removed. When the heating source of hydrothermal pretreatment is changed to microwave irradiation (MWI) in the presence or absence of an acid catalyst (usually sulfuric acid, acetic acid or phosphoric acid), it could be considered as microwave or microwave-assisted acid pretreatment [25]. Approximately $58.5 \%$ of hemicellulose was removed after MWI pretreatment $\left(210^{\circ} \mathrm{C}\right.$ for $\left.10 \mathrm{~min}\right)$ in the presence of $2 \% \mathrm{w} / \mathrm{w}$ $\mathrm{H}_{2} \mathrm{SO}_{4}$ while lignin remained in the solid residue. Approximately $81.8 \%$ of cellulose was recovered after treatment. However, lignin content increased in the solid residues after both hydrothermal and microwave-assisted acid treatment compared to native CS. These pretreatments as mentioned mainly remove hemicelluloses from the raw biomass, which in turn increased the relative lignin content. The latter is consistent with the reports of Silvertein et al. [26] and Wang et al. [27].

Alkaline pretreatment is one of the extensively studied chemical pretreatment methods, which aims to remove lignin and part of hemicellulose, by employing various alkali compounds [12]. Hemicellulose and lignin removal during the alkali pretreatment $\left(10 \%, w / w \mathrm{NaOH}, 121{ }^{\circ} \mathrm{C}, 30 \mathrm{~min}\right)$ led to an enrichment of cellulose which constituted $55.3 \%(w / w)$ of the pretreated biomass (Table 1$)$. Approximately $93 \%$ of CS cellulose was recovered after alkali treatment, while $42.2 \%$ and $9.2 \%$ of the total lignin and hemicellulose respectively were removed.

Table 1. Compositional analysis of pretreated cotton stalks (CS).

\begin{tabular}{|c|c|c|c|c|c|}
\hline \multirow[b]{2}{*}{ Component } & \multicolumn{5}{|c|}{ Content (g/100 g of Pretreated CS) } \\
\hline & $\begin{array}{l}\text { Microwave- } \\
\text { Assisted Acid a }\end{array}$ & Hydrothermal $^{b}$ & Alkali $^{\mathrm{c}}$ & Organosolv $^{d}$ & $\begin{array}{c}\text { Organosolv- } \\
\text { Hydrothermal }\end{array}$ \\
\hline Cellulose & $48.6 \pm 0.3$ & $47.3 \pm 2.1$ & $55.3 \pm 1.5$ & $77.0 \pm 0.7$ & $79.6 \pm 0.2$ \\
\hline Hemicellulose & $9.6 \pm 0.8$ & $3.9 \pm 0.1$ & $21.2 \pm 0.7$ & $1.4 \pm 0.3$ & $0.4 \pm 0.1$ \\
\hline Lignin Klason & $38.3 \pm 1.5$ & $39.1 \pm 1.3$ & $22.2 \pm 1.0$ & $9.7 \pm 0.6$ & $10.4 \pm 0.5$ \\
\hline Acid Soluble Lignin & $2.3 \pm 0.0$ & $1.7 \pm 0.0$ & $1.1 \pm 0.0$ & $1.1 \pm 0.1$ & $0.8 \pm 0.0$ \\
\hline Total lignin & $40.6 \pm 1.6$ & $40.8 \pm 1.3$ & $23.3 \pm 1.0$ & $10.8 \pm 0.7$ & $11.2 \pm 0.5$ \\
\hline
\end{tabular}

Organic solvent pretreatment (organosolv) can be used to provide treated cellulose suitable for enzymatic hydrolysis, using an organic or aqueous organic solvent to remove or decompose the network of lignin and possibly a part of the hemicellulose. The advantage of this process is the option to recover lignin as a value added product [13]. Solid recovery after organosolv treatment was $45.0 \%$ on dry basis. The cellulose content of organosolv treated CS samples was found to be $77.0 \%$ $(w / w)$, corresponding to a $91 \%$ of cellulose recovery (Table 1$)$. The hemicellulose and lignin contents dramatically decreased ( $96 \%$ and $81 \%$ removal, respectively). 
Organosolv pretreated CS was subjected to hydrothermal treatment and resulted in an almost hemicellulose free solid residue with low lignin content. Combined pretreatment led to a cellulose recovery of $71 \%$.

The results of Table 1 showed that the order for cellulose content was organosolv-hydrothermal treatment $>$ organosolv $>$ alkali treatment $>$ microwave-assisted acid pretreatment $>$ hydrothermal treatment and for lignin content it was hydrothermal treatment $>$ microwave-assisted acid pretreatment $>$ alkali treatment $>$ organosolv-hydrothermal treatment $>$ organosolv, respectively.

Various pretreatments of CS have been reported in literature i.e., alkali pretreatment $[4,6,26]$, high pressure-assisted alkali pretreatment and ultrasound-assisted alkali pretreatment $[27,28]$, steam explosion [29], liquid hot water pretreatment [23], dilute acid pretreatment [27,30], pretreatment with ILs [22], ozone treatment [4]. The outcome of each pretreatment in terms of lignin and hemicellulose solubilization depends on the pretreatment method and the conditions applied.

Pretreatment of lignocellulosic biomass represents one of the main economic costs in the process of bioethanol production. The operating cost of the combined pretreatment appears to be relatively high compared to a single step pretreatment, but the usage of biomass appears to be more efficient. The increased amount of ethanol produced translates into a higher ethanol concentration in the products stream, meaning more savings potential in the downstream purification process [31]. Moreover, lignin, the largest non-carbohydrate phenolic polymer not involved in the fermentation process to produce ethanol, could be obtained as co-product of the pretreatment process. Its unique material properties allow lignin utilization in value-added markets that can more likely afford the extra costs for pre-recovery by pretreatments, such as organosolv and ionic liquid, contributing to the competitiveness of bioethanol [32].

\subsection{Conversion of Pre-Treated CS to Bioethanol Applying PSSF}

Pretreated CS samples were converted to bioethanol applying PSSF at 15\% $(w / v)$ solids loading, in order to evaluate the pretreatment processes. The length of pre-hydrolysis step was set at $6 \mathrm{~h}$ while an enzyme load of $80 \mathrm{FPU} / \mathrm{g}$ cellulose was used [20]. In general, 7 to $33 \mathrm{FPU} / \mathrm{g}$ substrate are used for cellulose hydrolysis in lignocellulosic material, but in some cases higher enzyme loadings are necessary to efficiently hydrolyze the substrate $[27,33]$. Glucose release during pre-hydrolysis step was found to be dependent on the pretreatment applied and ranged from $18.77 \mathrm{~g} / \mathrm{L}$ (corresponding to a hydrolysis yield of $23.81 \%$ ) for hydrothermally treated CS (Figure 1a) to $35.81 \mathrm{~g} / \mathrm{L}$ (corresponding to a hydrolysis yield of $27.00 \%$ ) for organosolv-hydrothemally treated CS (Figure 1b).
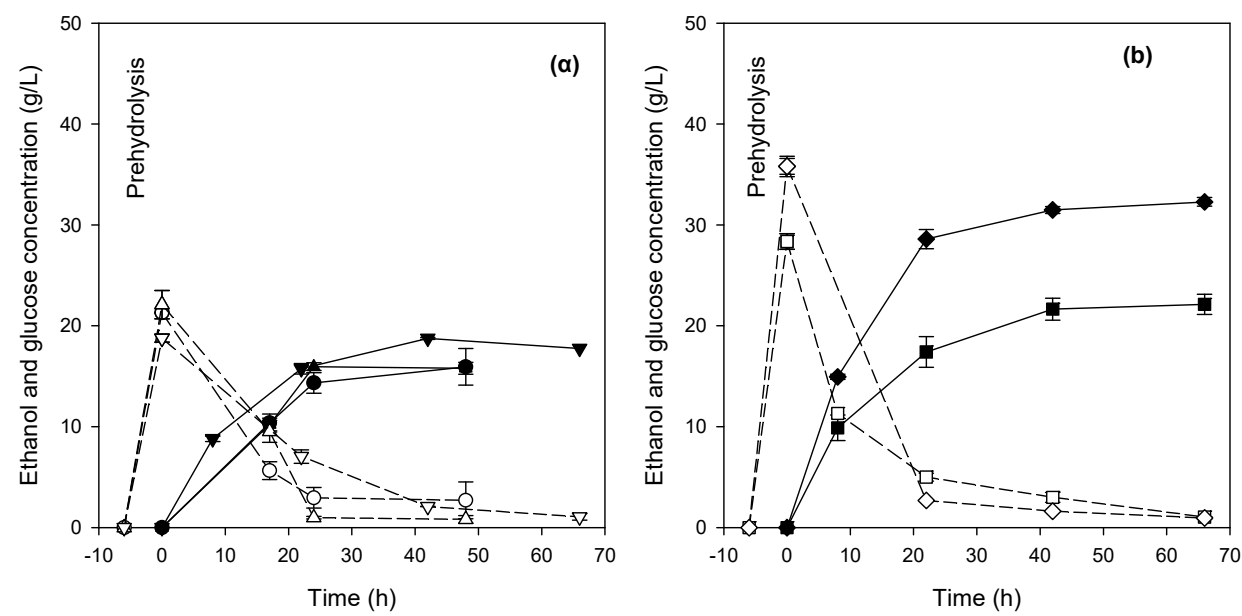

Figure 1. Bioethanol production from pretreated CS at 15\% $(w / v)$ substrate concentration after $6 \mathrm{~h}$ pre-hydrolysis. (a) Microwave-assisted acid pretreatment $(\bullet)$ ethanol and $(\bigcirc)$ glucose; alkali treatment $(\boldsymbol{\Lambda})$ ethanol and $(\triangle)$ glucose; hydrothermolysis $(\boldsymbol{\nabla})$ ethanol and $(\nabla)$ glucose; $(\mathbf{b})$ organosolv $(\boldsymbol{\square})$ ethanol and $(\square)$ glucose; combined organosolv-hydrothermolysis $(\diamond)$ ethanol and $(\diamond)$ glucose. 
The order of glucose concentration after $6 \mathrm{~h}$ pre-hydrolysis is organosolv-hydrothermal treatment $>$ organosolv $>$ alkali treatment $>$ microwave-assisted acid pretreatment $>$ hydrothermal treatment. Glucose release during the pre-hydrolysis step seemed nearly inversely proportional to the lignin content in the pretreated CS substrates, indicating that lignin removal facilitated cellulose hydrolysis. Lignin acts as a physical barrier and can affect enzymatic hydrolysis by limiting access of the cellulase to the cellulose in cell wall, as well as through the non-productive adsorption of cellulase. Non-productive absorption of cellulases to lignin is unavoidable and leads to reduced cellulase activity, requiring higher enzyme loadings or longer hydrolysis times to reach economic conversion levels [34]. Berlin et al. [35] reported that almost $70 \%$ of all enzymes added for hydrolysis can become unproductive due to the nonspecific adsorption by lignin.

Ethanol fermentation was initiated by the addition of dry yeast in the pre-hydrolyzed slurries (Figure 1). The high ethanol production rate due to glucose availability was observed in the first $24 \mathrm{~h}$ of fermentation, where yeast rapidly consumes glucose, followed by a decline in the production rate. Enzymes, which are present in the fermentation medium, continued to hydrolyze the substrate, at a slower rate due to suboptimal working temperatures $\left(30^{\circ} \mathrm{C}\right)$, and was the reason for the increase in bioethanol production after almost complete exhaustion of the initial glucose (Figure 1).

It is obvious that the pretreatment method affects severely the outcome of the process (Table 2). Ethanol production increased as the lignin content of the solid residues decreased. Fermentation of microwave-assisted acid and alkali treated samples resulted in the lowest ethanol production (approximately $15.9 \mathrm{~g} / \mathrm{L}$ ) (Table 2).

Table 2. Ethanol production from pretreated CS in relation to pretreatment method.

\begin{tabular}{ccccc}
\hline $\begin{array}{c}\text { Pretreatment Method } \\
\text { (Pretreatment Conditions) }\end{array}$ & Ethanol (g/L) & $\begin{array}{c}\text { Ethanol Yield } \\
(\mathbf{g} / \mathbf{1 0 0} \text { g Pretreated CS) }\end{array}$ & $\begin{array}{c}\text { Theoretical Ethanol } \\
\text { Yield }(\mathbf{\%}){ }^{\mathbf{1}}\end{array}$ & $\begin{array}{c}\text { Ethanol } \\
\text { Productivity }(\mathbf{g} / \mathbf{L} / \mathbf{h})\end{array}$ \\
\hline $\begin{array}{c}\text { Alkali treatment }(10 \% w / w \\
\left.\text { NaOH, } 121^{\circ} \mathrm{C}, 30 \mathrm{~min}\right)\end{array}$ & $15.9 \pm 0.7$ & $10.6 \pm 0.5$ & $33.9 \pm 1.5$ & $0.33 \pm 0.02$ \\
$\begin{array}{c}\text { Microwave-assisted acid } \\
\text { pretreatment }\left(210^{\circ} \mathrm{C}, 10 \mathrm{~min},\right. \\
2 \%, w / w \text { sulfuric acid) }\end{array}$ & $15.9 \pm 1.8$ & $10.6 \pm 1.2$ & $38.5 \pm 1.3$ & $0.33 \pm 0.02$ \\
$\begin{array}{c}\text { Hydrothermolysis }\left(175^{\circ} \mathrm{C},\right. \\
\left.2 \mathrm{~h}, \mathrm{~N}_{2}\right)\end{array}$ & $18.8 \pm 0.3$ & $12.5 \pm 0.3$ & $54.6 \pm 1.3$ & $0.45 \pm 0.04$ \\
$\begin{array}{c}\text { Organosolv } \\
\text { Organosolv and hydrothermal } \\
\text { treatment }\left(175^{\circ} \mathrm{C}, 2 \mathrm{~h}, \mathrm{~N}_{2}\right)\end{array}$ & $22.1 \pm 0.2$ & $14.8 \pm 0.1$ & $33.8 \pm 0.4$ & $0.52 \pm 0.01$ \\
\hline
\end{tabular}

${ }^{1}$ Calculated by Equation (4).

The individual effect of the organosolv and hydrothermal pretreatments acted synergistically, producing significant improvement in ethanol production. The maximum attainable ethanol production was $32.3 \mathrm{~g} / \mathrm{L}$ (corresponding to an ethanol yield of $47.6 \%$ ) after fermentation of the solid residue resulted from the combined pretreatment. Productivities ranged from 0.33 to $0.52 \mathrm{~g} / \mathrm{L} / \mathrm{h}$ (Table 2). The organosolv-hydrothermally treated CS was used in further experimentations.

\subsection{Effect of Organosolv-Hydrothermally Treated CS Concentration and Pre-Hydrolysis Time on Bioethanol Production}

The effect of pre-hydrolysis time and substrate concentration on bioethanol production was evaluated. At $15 \%(w / v)$ substrate concentration, glucose concentration after $6 \mathrm{~h}$ pre-hydrolysis (PSSF (6 h pre-hydrolysis)) was $35.8 \mathrm{~g} / \mathrm{L}$ (corresponding to $27.0 \%$ cellulose conversion), while extending pre-hydrolysis time to $14 \mathrm{~h}$ glucose increased by approximately $49 \%(69.6 \mathrm{~g} / \mathrm{L}$, corresponding to $52.5 \%$ cellulose conversion) (Figure 2). The $14 \mathrm{~h}$ pre-hydrolyzed slurry was fermented to ethanol by the yeast and resulted in $39.7 \mathrm{~g} / \mathrm{L}$ bioethanol, corresponding to an ethanol yield of $58.5 \%$, after $30 \mathrm{~h}$ of fermentation (Figure 2). 


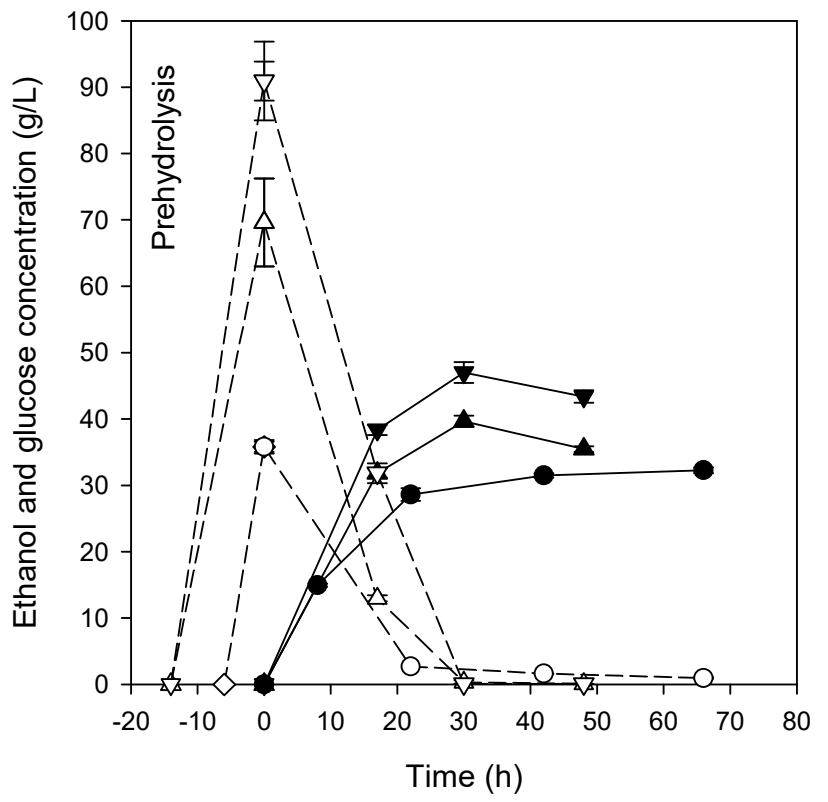

Figure 2. Bioethanol production from organosolv-hydrothermally treated CS at $15 \%$ and $20 \%(w / v)$ substrate concentration applying different pre-hydrolysis times. Symbols: $(\bullet)$ ethanol and $(\bigcirc)$ glucose 6 h pre-hydrolysis at $15 \%(w / v)$ substrate concentration; $(\boldsymbol{\Delta})$ ethanol and $(\triangle)$ glucose $14 \mathrm{~h}$ pre-hydrolysis at $15 \%(w / v)$ substrate concentration; $(\boldsymbol{\nabla})$ ethanol and $(\nabla)$ glucose $14 \mathrm{~h}$ pre-hydrolysis at $20 \%(w / v)$ substrate concentration.

The increase in bioethanol production compared to $6 \mathrm{~h}$ pre-hydrolysis prior to fermentation was $18 \%$. The higher availability of glucose at the beginning of the fermentation affected the fermentation time and as a consequence the productivity of the process. According to Ma et al. [36] sugar transportation to yeast cell is the rate limiting step of glycolysis pathway in Saccharomyces cerevisiae; a sugar concentration gradient across the plasma membrane is needed to activate this process, thus the presence of fermentable sugars at the beginning of the fermentation could have enhanced this activation resulting in reduced fermentation time. The productivity of the PSSF ( $6 \mathrm{~h}$ pre-hydrolysis) process was found to be $0.49 \mathrm{~g} / \mathrm{L} / \mathrm{h}$, while that of the PSSF (14 h pre-hydrolysis) was $1.32 \mathrm{~g} / \mathrm{L} / \mathrm{h}$. The ethanol produced by the PSSF (14 h pre-hydrolysis) process is close to the limit for economical distillation [15]. It is evident that the increase in pre-hydrolysis time had a positive effect on bioethanol production. In some previous studies no effect, or a small negative effect, has been reported after pre-hydrolysis prior to fermentation [37], while a clear improvement in ethanol yield has been found in other studies when using pre-hydrolysis $[17,38]$.

In an attempt to increase ethanol titer and meet the demands for economical distillation, higher substrate concentration was used $(20 \% w / v)$, while the pre-hydrolysis time was set at $14 \mathrm{~h}$. The choice of pre-hydrolysis time for the $20 \%(w / v)$ substrate concentration was based on previous results [20]. Glucose in the pre-hydrolyzed slurry was found to be $90.9 \mathrm{~g} / \mathrm{L}$ (corresponding to $51.5 \%$ cellulose conversion), which was rapidly converted to ethanol by the yeast (Figure 2). Ethanol production reached $47.0 \mathrm{~g} / \mathrm{L}$ (corresponding to an ethanol yield of $52 \%$ ) after $30 \mathrm{~h}$ of fermentation leading to a productivity of $1.57 \mathrm{~g} / \mathrm{L} / \mathrm{h}$. Even though high ethanol titer was achieved, ethanol yield ranged at a moderate level. In general, for high efficiency bioethanol production the balance between ethanol concentration and yield is very important. One way to improve the overall performance of PSSF could be the recycling the solid residue contained the unhydrolyzed carbohydrates, adsorbed enzymes, and yeast cells, as demonstrated by Qin et al. [39].

A comparison of different processes reported in literature for bioethanol production from pretreated CS is summarized on Table 3. Compared to the reported values, bioethanol production obtained in this work is excellent. 
Table 3. Comparison of different processes for ethanol production from pretreated CS.

\begin{tabular}{|c|c|c|c|c|c|c|}
\hline Type of Pretreatment & $\begin{array}{c}\text { Fermenting } \\
\text { Microorganism }\end{array}$ & $\begin{array}{l}\text { Solids Loading } \\
\quad(\%, w / v)\end{array}$ & $\begin{array}{l}\text { Type of } \\
\text { Process }\end{array}$ & $\begin{array}{c}\text { Ethanol } \\
\text { Conc. }(g / L)\end{array}$ & $\begin{array}{l}\text { Productivity } \\
\text { (g/L/h) }\end{array}$ & Reference \\
\hline $\begin{array}{l}\text { Alkaline }(4 \% \text { w } / v \mathrm{NaOH}, \\
\left.121^{\circ} \mathrm{C} / 15 \mathrm{psi} \text { for } 60 \mathrm{~min}\right)\end{array}$ & $\begin{array}{l}\text { Pichia kudriavzevii } \\
\text { HOP-1 }\end{array}$ & 10.0 & $\operatorname{PSSF}(12 \mathrm{~h})^{1}$ & 19.48 & 0.41 & [4] \\
\hline $\begin{array}{l}\text { Ozone treatment (ozone } \\
\text { concentration of } 45 \mathrm{mg} / \mathrm{L} \\
\text { and flow rate of } 0.37 \mathrm{~L} / \mathrm{min} \\
\text { for } 150 \mathrm{~min} \text { ) }\end{array}$ & $\begin{array}{l}\text { P. kudriavzevii } \\
\text { HOP-1 }\end{array}$ & 10.0 & SHF & 10.96 & 0.46 & [4] \\
\hline $\begin{array}{l}\text { Dilute acid }(0.8 \% v / v(1.5 \% \\
w / v), \mathrm{H}_{2} \mathrm{SO}_{4} \text { at } 180^{\circ} \mathrm{C} \text { for } \\
12 \mathrm{~min})\end{array}$ & $\begin{array}{l}\text { S. cerevisiae } \\
\text { Thermosacc }{ }^{\circledR} \text { Dry }\end{array}$ & 10.0 & SSF & 12.88 & 0.13 & [33] \\
\hline $\begin{array}{l}\text { Liquid Hot Water (severity } \\
\text { factor: } 4.34 \text { ) }\end{array}$ & Dry yeast & 8.0 & $\operatorname{PSSF}(24 \mathrm{~h})^{1}$ & 14.0 & 0.12 & [23] \\
\hline $\begin{array}{l}\text { Alkaline }(3 \% \mathrm{NaOH} \text { at } \\
\text { room temperature for } 24 \mathrm{~h}) \text {. } \\
\text { Two-stage acid hydrolysis } \\
\text { of cellulose }\end{array}$ & $\begin{array}{l}\text { S. cerevisiae VS3 } \\
\text { and Pichia stipitis } \\
\text { NCIM-3498 }\end{array}$ & $10.0^{3}$ & - & 11.64 & 0.24 & [6] \\
\hline $\begin{array}{l}\text { High pressure-assisted } \\
\text { alkali pretreatment (HPAP) } \\
\left(3.0 \% \mathrm{NaOH}, 121^{\circ} \mathrm{C} \text {, }\right. \\
130 \mathrm{kPa} \text { for } 40 \mathrm{~min})\end{array}$ & S. cerevisiae & $2.0^{2}$ & SHF & 3.32 & 0.07 & [27] \\
\hline $\begin{array}{l}\text { Ionic Liquids (EMIMAc) } \\
\left(150^{\circ} \mathrm{C} \text { for } 30 \mathrm{~min}\right)\end{array}$ & $\begin{array}{l}\text { S. cerevisiae NRRL } \\
\text { Y-132 }\end{array}$ & $15.0^{2}$ & SHF & 22.9 & 1.92 & [22] \\
\hline $\begin{array}{l}\text { Ultrasonication and hot } \\
\text { water and ligninolytic } \\
\text { enzymes pretreatment }\end{array}$ & $\begin{array}{l}\text { S. cerevisiae } \\
\text { Ethanol Red }\end{array}$ & $10.0^{2}$ & SHF & 5.5 & 0.08 & [40] \\
\hline $\begin{array}{l}\text { Organosolv and } \\
\text { hydrothermal treatment }\end{array}$ & Dry yeast & 20.0 & $\operatorname{PSSF}(14 \mathrm{~h})^{1}$ & 47.0 & 1.57 & Present study \\
\hline
\end{tabular}

It is evident that ethanol production from CS depends on a number of different parameters that should be considered for the optimal outcome, i.e., type of pretreatment and the changes these cause in the composition and structure of the solid residue, type of enzymes, solids and enzyme loading, fermenting microorganism, process configuration etc.

Despite the high ethanol titer achieved in the present study, further efforts will be devoted to better exploitation of cellulose content of pretreated CS through recycling of PSFF or implementation of fed-batch process.

\section{Conclusions}

Cotton stalk can be a promising feedstock for bio-ethanol production and preferably suited to the biorefinery approach due to its worldwide abundance, its high carbohydrate content and the fact that it does not compete with the land available for food and feed production. In the present study alkali pretreatment, microwave-assisted acid pretreatment, organosolv, hydrothermal treatment and combination of the organosolv and hydrothermal treatment were comparatively investigated to produce ethanol from CS applying PSSF at high solids loading. Cellulose, hemicellulose and lignin content of the pretreated materials depended on the type of pretreatment applied. Fermentation of the pretreated CS samples carried out by the PSSF process at 15\% $(w / v)$ substrate concentration revealed that ethanol production increased as the lignin content of the solid residues decreased. Among the different pretreatments, sequentially organosolv and hydrothermal pretreatment of CS generated the highest ethanol production. The extent of pre-hydrolysis and substrate concentration were important factors that affected ethanol production as well as the productivity of the process. The highest ethanol concentration reached in the present study was $47.0 \mathrm{~g} / \mathrm{L}$ at $20 \%(w / v)$ substrate concentration, applying $14 \mathrm{~h}$ pre-hydrolysis prior to SSF. Under the conditions described in the present study $235 \mathrm{~g}$ of ethanol from $1 \mathrm{~kg}$ organosolv-hydrothermally treated CS could be obtained. 
Author Contributions: Conceptualization, K.G.K., A.A.L., N.P., D.K. and D.M.; Methodology, K.G.K. and D.M.; Investigation, K.D., T.P., A.L.; Writing-Original Draft Preparation, D.M.; Writing-Review \& Editing, all authors.

Acknowledgments: The authors would like to thank Theofanis Gemtos of the Laboratory of Farm Mechanization, Department of Agriculture, Crop Production and Rural Environmnent, University of Thessaly for providing the cotton stalks. The authors would also like to thank Novozymes Corporation for generously providing the cellulose enzyme samples.

Conflicts of Interest: The authors declare no conflict of interest.

\section{References}

1. De Bhowmick, G.; Sarmaha, A.K.; Sen, R. Lignocellulosic biorefinery as a model for sustainable development of biofuels and value added products. Bioresour. Technol. 2018, 247, 1144-1154. [CrossRef] [PubMed]

2. Lokko, Y.; Heijde, M.; Schebesta, K.; Scholtès, P.; Van Montagu, M.; Giacca, M. Biotechnology and the bioeconomy-Towards inclusive and sustainable industrial development. New Biotechnol. 2018, 40, 5-10. [CrossRef] [PubMed]

3. Zabed, H.; Sahu, J.N.; Suely, A.; Boyce, A.N.; Faruq, G. Bioethanol production from renewable sources: Current perspectives and technological progress. Renew. Sustain. Energy Rev. 2017, 71, 475-501. [CrossRef]

4. Kaur, U.; Oberoi, H.S.; Bhargav, V.K.; Sharma-Shivappa, R.; Dhaliwal, S.S. Ethanol production from alkaliand ozone-treated cotton stalks using thermotolerant Pichia kudriavzevii HOP-1. Ind. Crop Prod. 2012, 37, 219-226. [CrossRef]

5. Food and Agriculture Organisation of the United Nations (FAO). Available online: http://www.fao.org/ faostat/en/\#data/QC (accessed on 16 November 2018).

6. Keshav, P.K.; Shaik, N.; Koti, S.; Linga, V.R. Bioconversion of alkali delignified cotton stalk using two-stage dilute acid hydrolysis and fermentation of detoxified hydrolysate into ethanol. Ind. Crop Prod. 2018, 91,323-331. [CrossRef]

7. Chen, H.; Liu, J.; Chang, X.; Chen, D.; Xue, Y.; Liu, P.; Lin, H.; Han, S. A review on the pretreatment of lignocellulose for high-value chemicals. Fuel Process. Technol. 2017, 160, 196-206. [CrossRef]

8. Sun, S.; Sun, S.; Cao, X.; Sun, R. The role of pretreatment in improving the enzymatic hydrolysis of lignocellulosic materials. Bioresour. Technol. 2016, 199, 49-58. [CrossRef]

9. Galbe, M.; Zacchi, G. Pretreatment: The key to efficient utilization of lignocellulosic materials. Biomass Bioenergy 2012, 46, 70-78. [CrossRef]

10. Mathew, A.K.; Parameshwaran, B.; Sukumaran, R.K.; Pandey, A. An evaluation of dilute acid and ammonia fiber explosion pretreatment for cellulosic ethanol production. Bioresour. Technol. 2016, 199, 13-20. [CrossRef]

11. Zhuang, X.; Wang, W.; Yu, Q.; Qi, W.; Wang, Q.; Tan, X.; Zhou, G.; Yuan, Z. Liquid hot water pretreatment of lignocellulosic biomass for bioethanol production accompanying with high valuable products. Bioresour. Technol. 2016, 199, 68-75. [CrossRef]

12. Kim, J.S.; Lee, Y.Y.; Kim, T.H. A review on alkaline pretreatment technology for bioconversion of lignocellulosic biomass. Bioresour. Technol. 2016, 199, 42-48. [CrossRef] [PubMed]

13. Zhang, K.; Pei, Z.; Wang, D. Organic solvent pretreatment of lignocellulosic biomass for biofuels and biochemicals: A review. Bioresour. Technol. 2016, 199, 21-33. [CrossRef] [PubMed]

14. Gupta, A.; Verma, J.P. Sustainable bio-ethanol production from agro-residues: A review. Renew. Sustain. Energy Rev. 2015, 41, 550-567. [CrossRef]

15. Koppram, R.; Tomás-Pejó, E.; Xiros, C.; Olsson, L. Lignocellulosic ethanol production at high-gravity: Challenges and perspectives. Trends Biotechnol. 2014, 32, 46-53. [CrossRef] [PubMed]

16. Modenbach, A.A.; Nokes, S.E. Enzymatic hydrolysis of biomass at high-solids loadings-A review. Biomass Bioenergy 2013, 56, 526-544. [CrossRef]

17. Hoyer, K.; Galbe, M.; Zacchi, G. The effect of prehydrolysis and improved mixing on high-solids batch simultaneous saccharification and fermentation of spruce to ethanol. Process. Biochem. 2013, 48, $289-293$. [CrossRef]

18. Kalogiannis, K.; Stefanidis, S.; Marianou, A.; Michailof, C.; Kalogianni, A.; Lappas, A. Lignocellulosic biomass fractionation as a pretreatment step for production of fuels and green chemicals. Waste Biomass Valoriz. 2015, 6, 781-790. [CrossRef] 
19. Dogaris, I.; Karapati, S.; Mamma, D.; Kalogeris, E.; Kekos, D. Hydrothermal processing and enzymatic hydrolysis of sorghum bagasse for fermentable carbohydrates production. Bioresour. Technol. 2009, 100, 6543-6549. [CrossRef]

20. Chilari, D.; Dimos, K.; Georgoula, G.; Paschos, T.; Mamma, D.; Louloudi, A.; Papayannakos, N.; Kekos, D. Bioethanol production from alkali-treated cotton stalks at high solids loading applying non-isothermal simultaneous saccharification and fermentation. Waste Biomass Valoriz. 2017, 8, 1919-1929. [CrossRef]

21. Sluiter, A.; Hames, B.; Ruiz, R.; Scarlata, C.; Sluiter, J.; Templeton, D.; Crocker, D. Determination of Structural Carbohydrates and Lignin in Biomass; Technical Report NREL/TP-510-42618; National Renewable Energy Laboratory: Golden, CO, USA, 2012. Available online: https://www.nrel.gov/docs/gen/fy13/42618.pdf (accessed on 16 November 2018).

22. Haykir, N.I.; Bakir, U. Ionic liquid pretreatment allows utilization of high substrate loadings in enzymatic hydrolysis of biomass to produce ethanol from cotton stalks. Ind. Crop Prod. 2013, 51, 408-414. [CrossRef]

23. Jiang, W.; Chang, S.; Li, H.; Oleskowicz-Popiel, P.; Xu, J. Liquid hot water pretreatment on different parts of cotton stalk to facilitate ethanol production. Bioresour. Technol. 2015, 176, 175-180. [CrossRef] [PubMed]

24. Agblevor, F.A.; Batz, S.; Trumbo, J. Composition and ethanol production potential of cotton gin residues. In Biotechnology for Fuels and Chemicals. Applied Biochemistry and Biotechnology; Davison, B.H., Lee, J.W., Finkelstein, M., McMillan, J.D., Eds.; Humana Press: Totowa, NJ, USA, 2003; pp. 219-230.

25. Li, H.; Qu, Y.; Yang, Y.; Chang, S.; Xu, J. Microwave irradiation-A green and efficient way to pretreat biomass. Bioresour. Technol. 2016, 199, 34-41. [CrossRef] [PubMed]

26. Silverstein, R.A.; Chen, Y.; Sharma-Shivappa, R.R.; Boyette, M.D.; Osborne, J. A comparison of chemical pretreatment methods for improving saccharification of cotton stalks. Bioresour. Technol. 2007, 98, 3000-3011. [CrossRef] [PubMed]

27. Wang, M.; Zhou, D.; Wang, Y.; Wei, S.; Yang, W.; Kuang, M.; Ma, L.; Fang, D.; Xu, S.; Du, S. Bioethanol production from cotton stalk: A comparative study of various pretreatments. Fuel 2016, 184, 527-532. [CrossRef]

28. Du, S.K.; Su, X.; Yang, W.; Wang, Y.; Kuang, M.; Ma, L.; Fang, D.; Zhou, D. Enzymatic saccharification of high pressure assist-alkali pretreated cotton stalk and structural characterization. Carbohydr. Polym. 2016, 140, 279-286. [CrossRef] [PubMed]

29. Huang, Y.; Wei, X.; Zhou, S.; Liu, M.; Tu, Y.; Li, A.; Chen, P.; Wang, Y.; Zhang, X.; Tai, H.; et al. Steam explosion distinctively enhances biomass enzymatic saccharification of cotton stalks by largely reducing cellulose polymerization degree in G. barbadense and G. hirsutum. Bioresour. Technol. 2015, 181, 224-230. [CrossRef] [PubMed]

30. Gaur, R.; Soam, S.; Sharma, S.; Gupta, R.P.; Bansal, V.R.; Kumar, R.; Tuli, D.K. Bench scale dilute acid pretreatment optimization for producing fermentable sugars from cotton stalk and physicochemical characterization. Ind. Crop Prod. 2016, 83, 104-112. [CrossRef]

31. Da Silva, A.R.G.; Errico, M.; Rong, B.-G. Techno-economic analysis of organosolv pretreatment process from lignocellulosic biomass. Clean Technol. Environ. Policy 2018, 20, 1401-1412. [CrossRef]

32. Ragauskas, A.J.; Beckham, G.T.; Biddy, M.J.; Chandra, R.; Chen, F.; Davis, M.F.; Davison, B.H.; Dixon, R.A.; Gilna, P.; Keller, M.; et al. Lignin Valorization: Improving Lignin Processing in the Biorefinery. Science 2014, 344, 1246843. [CrossRef]

33. McIntosh, S.; Vancov, T.; Palmer, J.; Morris, S. Ethanol production from cotton gin trash using optimised dilute acid pretreatment and whole slurry fermentation processes. Bioresour. Technol. 2014, 173, 42-51. [CrossRef]

34. Lu, X.; Zheng, X.; Li, X.; Zhao, J. Adsorption and mechanism of cellulase enzymes onto lignin isolated from corn stover pretreated with liquid hot water. Biotechnol. Biofuels 2016, 9, 118. [CrossRef] [PubMed]

35. Berlin, A.; Balakshin, M.; Gilkes, N.; Kadla, J.; Maximenko, V.; Kubo, S.; Saddler, J. Inhibition of cellulase, xylanase and beta-glucosidase activities by softwood lignin preparations. J. Biotechnol. 2006, 125, 198-209. [CrossRef] [PubMed]

36. Ma, T.; Kosa, M.; Sun, Q. Fermentation to bioethanol/biobutanol. In Materials for Biofuels; Ragauskas, A., Ed.; World Scientific Publishing Co. Pte. Ltd.: Singapore, 2014; pp. 155-189.

37. Gladis, A.; Bondesson, P.-M.; Galbe, M.; Zacchi, G. Influence of different SSF conditions on ethanol production from corn stover at high solids loadings. Energy Sci. Eng. 2015, 3, 481-489. [CrossRef] 
38. Li, X.; Lu, J.; Zhao, J.; Qu, Y. Characteristics of corn stover pretreated with liquid hot water and fed-batch semi-simultaneous saccharification and fermentation for bioethanol production. PLoS ONE 2014, 9, e95455. [CrossRef] [PubMed]

39. Qin, L.; Zhao, X.; Li, W.-C.; Zhu, J.-Q.; Liu, L.; Li, B.-Z.; Yuan, Y.-J. Process analysis and optimization of simultaneous saccharification and co-fermentation of ethylenediamine-pretreated corn stover for ethanol production. Biotechnol. Biofuels 2018, 11, 118. [CrossRef] [PubMed]

40. Plácido, J.; Imam, T.; Capareda, S. Evaluation of ligninolytic enzymes, ultrasonication and liquid hot water as pretreatments for bioethanol production from cotton gin trash. Bioresour. Technol. 2013, 139, 203-208. [CrossRef] [PubMed] 